EDİRNE KIRMIZISI’NIN EDİRNE İLINNE KENT KİMLİĞí KAZANDIRMASINDAKİ ROLÜ

THE ROLE OF EDIRNE RED IN ATTRACTING A URBAN IDENTITY TO EDIRNE PROVINCE

Orkun AKMAN", Emel GÖNENÇ GÜLER ${ }^{* *}$

Geliş Tarihi: 16.09.2021

Kabul Tarihi:22.11.2021

(Received) (Accepted)

ÖZ: Tarih boyunca birçok medeniyete ev sahipliği yapan Edirne ili, tarihi ve kültürel miras açısından oldukça zengin bir kent konumundadır. Türkiye'deki turizm potansiyelinin yüksek olduğu kentlerin başında gelen Edirne ilinin sahip olduğu zenginlikler kente bir kimlik kazandırmaktadır. Jeopolitik konumu nedeniyle günümüzde Traklardan Osmanlılara kadar birçok medeniyetten izler taşıyan Edirne ili tarihi ve kültürel birikime sahip olmanın yanı sıra bünyesinde pek çok kültürel ve turistik ögeyi barındırmaktadır. Bu ögelerden biri de, tüm dünyada "Edirne" ismiyle anılan, kırmızı renginin bir tonu olan Edirne Kırmızısı'dır. Yurt dışında daha çok Fransızca ismi "Rouge d'Andrinople" olarak bilinen Edirne Kırmızısı, sadece bir rengi değil, kültürel bir değer olarak somut ve soyut kavramları da temsil etmektedir. Oldukça zahmetli bir boyama süreci sonrası elde edilen, uğrunda çokça emek ve paranın harcandığı tarihi bir renk olarak dikkat çeken Edirne Kırmızısı, Sanayi Devrimi sonrası endüstrideki makineleşmenin etkisiyle zamanla unutulmaya yüz tutmuştur.

Edirne'de 2017 yılında mahalli bir gazetede yayımlanan yazı dizisi sonrası tekrar gündeme gelen Edirne Kırmızısı ile ilgili yapılan çalışmaların Edirne ili kent kimliğine etkisinin ortaya konmasının amaçlandığı bu çalışmada nitel araştırma yöntemleri kullanılmıştır. Edirne'de yaşayan ve kentsel turizmin gelişmesine katkıda bulunduğu düşünülen 20 temsilci belirlenerek kendilerine belirlenmiş açı uçlu sorular yöneltilmiş̧ir. Alınan cevaplar doğrultusunda Edirne Kırmızısı; bilinirlilik, zaman, ürün çeşitlendirmesi, geleceğe yönelik olumlu ve olumsuz tahminler boyutunda değerlendirilmiş ve toplanan veriler MAXQDA 2020 programı aracılığıyla analiz edilmiştir. Gelecekte Edirne Kırmızısı ile ilgili yapılacak faaliyetlerin planlanmasında tüm kent paydaşları tarafından kullanılabilecek bu çalışmanın Edirne ilinin tanıtımına, kentsel kimliğine, turizmine, kültürüne ve ekonomisine sürdürülebilir bir şekilde katkı sunması hedeflenmiştir.

Anahtar Kelimeler: Kent Kimliği, Edirne, Edirne Kırmızısı

ABSTRACT: Edirne province, which has hosted many civilizations throughout history, is a very rich city in terms of historical and cultural heritage. The richness of Edirne, which is one of the cities with high tourism potential in Turkey, gives the city an identity. Due to its geopolitical location, Edirne, which has traces of many civilizations from the Thracians to the Ottomans, has historical and cultural accumulation as well as many cultural and

\footnotetext{
* Trakya Üniversitesi, orkunakman@ trakya.edu.tr, 0000-0002-4308-7770.

*** Prof. Dr., Trakya Üniversitesi, emelgguler@ trakya.edu.tr, 0000-0002-3214-0206.
} 
touristic items. One of these elements is Edirne Red, a tone of red, which is known as "Edirne" all over the world. Edirne Red, more commonly known as "Rouge d'Andrinople" abroad, represents not only a color but also concrete and abstract concepts as a cultural value. Edirne Red, which draws attention as a historical color obtained after a very laborious dyeing process and for which a lot of effort and money was spent, has been forgotten over time with the effect of mechanization in the industry after the Industrial Revolution.

Qualitative research methods were used in this study, which aimed to reveal the effect of the studies on Edirne Red, which after a series of articles published in a local newspaper in Edirne in 2017, on the urban identity of Edirne. 20 representatives living in Edirne who are thought to contribute to the development of urban tourism were determined and open-ended questions were asked to them. In line with the answers received, Edirne Red; awareness, time, product, positive and negative predictions for the future, and the collected data were analyzed through the MAXQDA 2020 program. It is aimed that this study, which can be used by all city stakeholders in the planning of future activities related to Edirne Red, will contribute to the promotion, urban identity, tourism, culture and economy of Edirne province in a sustainable way.

Key Words: Urban Identity, Edirne, Edirne Red

\section{EXTENDED ABSTRACT}

Tourism provides assistance to the city center from an economic, social and perspective. Urban identity, which is one of the important components of tourism, also creates an substructure for tourism-oriented activities in a destination. Destinations that have managed to preserve their identity or create a new identity for themselves provide significant income from tourism activities. The concept of colour is also an important component in the promotion of a destination as the concept of urban identity. Colours, which are used as an important tourism element in the city promotion, not only reflect the identity of a city, but also give some tips about its cultural accumulation.

Edirne, which has hosted many civilizations from the Thracians to the Ottomans throughout history with its geopolitical location, geographical features and natural components, has a significant historical and cultural accumulation. Edirne destination, where many historical and architectural monuments such as bridges, religious buildings, baths, fountains, and caravanserais are located, also hosts many cultural values such as Kirkpınar Oil Wrestling, Kakava and Hidrellez Festivals. All these features make Edirne an outstanding tourism destination and also give Edirne an urban identity. One of the cultural values that make up the urban identity of Edirne is Edirne Red, a tone of red, which is known as "Edirne Red" all over the world. Edirne Red, which is mostly known by its French name "Rouge d'Andrinople" abroad, draws attention as a historical colour obtained after a very laborious dyeing process, for which a lot of effort and money was spent. Edirne Red, which owes its existence to a natural dye such as madder, has been forgotten with the effect of mechanization in the industry after the Industrial Revolution.

Edirne Red, which was first known as Turkish Red in Europe, reached a great reputation first in Europe and then all over the world as a result of two dyers being taken from Edirne, which is famous for its dyers, to France. Edirne Red, which has become one of the most important figures of the European textile market especially in the 18th and 19th 
centuries, has managed to preserve its mystery for many years based on the masterapprentice teaching. Edirne Red, which came up again after a series of articles published in a local newspaper in Edirne in 2017, is being tried to be brought back into the city's memory as a cultural value.

In this research, it is aimed to obtain the results that will provide the basis for the branding of Edirne Red by reintroducing it to the city identity of Edirne and creating competitive power in destination marketing. The study also aims to bring together the works carried out to bring Edirne Red to the urban identity and tourism and to put the colour on an institutional basis. This study, which is important in terms of contributing to the planning of activities to be carried out by all city stakeholders in the future in order to reveal the effect of Edirne Red on the urban identity of Edirne, is aimed to contribute to the identity, tourism, promotion, culture and economy of the city in a sustainable way.

Qualitative research methods were used, open-ended questions were asked to the participants who took an active role on Edirne Red studies, which has the authority to develop the concepts of urban identity and urban tourism in Edirne, and who are thought to contribute to future studies. The findings were supported by quotations reflecting the views of the participants, and Edirne Red was evaluated in terms of awareness, time, positive and negative predictions for the future, and product. The collected data were then analyzed in the MAXQDA 2020 qualitative data analysis program. In this research, the description of Edirne Red as a cultural element reveals the validity of the efforts to bring the colour into the identity of the destination.

The findings of the research show that Edirne Red, which came to the forefront of the city after a series of articles published in a local newspaper in 2017, was the subject of some professional projects and meetings, scientific studies and various communication tools, and that Trakya University's studies on this subject contributed to the awareness of Edirne Red.

The data reveal that Edirne Red covers more than one concept. In line with the answers received from the participants, it reflects that Edirne Red represents not only a colour but also concrete and abstract concepts. In particular, the fact that $30 \%$ of the participants stated Edirne Red as a cultural element coincides with the fact that the efforts to bring Edirne Red to the identity of the city have gained validity.

The first appearance of Edirne Red in a textile product had an impact on the participants as well. While almost all of the participants diversify Edirne Red with a textile product such as ties, shawls and scarves, it is meaningful that half of the participants say souvenirs. The data obtained from the research revealed that Edirne Red can also be used in the food industry. Participants stated that the colour tone of Edirne Red can be applied to products such as ice cream, Turkish delight and almond paste, and thus the variety of usage of the colour will increase. In addition, the participants who stated that Edirne Red can be used as a material for the automotive sector and public transportation stated that the use of the colour as a commercial product both locally and worldwide could become widespread.

The results of analysis reveal the importance of Edirne Red for the urban culture and economy. The fact that $55 \%(n=11)$ of the participants stated that Edirne Red will become a brand in the future also coincides with the "brand city" concept of Edirne. In 
addition, this result can be interpreted as Edirne Red will contribute positively to the rebranding image of Edirne destination.

This research, which compiles the studies on Edirne Red, which is discussed in terms of urban identity and urban tourism, is important for guiding future studies. Cultural tourism and urban tourism will gain more importance within the framework of alternative tourism opportunities, replacing mass tourism. Edirne Red, with the historical, cultural, touristic and geographical features it represents, will contribute to making the city of Edirne one of the world's most preferred destinations.

\section{GíRiş}

Küreselleşmenin yaygınlaşması, seyahat etme imkânlarının artması ve bir yerden bir yere ulaşmanın kolay hale gelmesiyle ile birlikte kentler yeni turizm stratejileri geliştirerek daha fazla turist ağırlama hedefine girişmişlerdir. Sahip oldukları doğal, tarihi, kültürel ve mimari değerleri çeşitli yollarla tanıtarak turizmden elde ettikleri geliri artırmay1 hedefleyen kentler, var olan turizm potansiyellerini iyileştirmeye çalıştıkları gibi yeni turistik objeler de üretmeye başlamışlardır.

Bir kentin marka kimliğinin oluşmasında o kente özgü çok sayıda kaynak, değer, sembol, grafik, renk kullanılmaktadır (Meyers ve Lubliner, 2003; Rainisto, 2003; İçli ve Çopur, 2008). Kimi kentler tarihi ve kültürel kimlikleriyle, kimi kentler de renklerle özdeşleşmiştir. Dolayısıyla bazı kentler marka değeri oluştururken renk kavramını da kullanarak yeni bir imaj yaratma eğilimine girmiş̧lerdir. Tarihi ve kültürel birikimi nedeniyle her yıl çok sayıda yerli ve yabancı turistin ziyaret ettiği Edirne ili bünyesinde somut ve somut olmayan birçok kültürel ögeyi barındırmaktadır. Tüm dünyada "Edirne" ön ismiyle bilinen bir renge sahip olan, kent kimliği ve renk kavramı bileșenlerinin doğal yollarla birlikteliğinin sağlandığı ender kentlerden biri olarak dikkat çeken Edirne ilinin sahip olduğu kültürel değerlerden biri de Fransızca "Rouge d'Andrinople" ismiyle bilinen Edirne Kırmızısı'dır.

Oldukça uzun ve zor bir süreçten geçtikten sonra doğal yöntemlerle elde edilen bir renk olan Edirne Kırmızısı, 18. yüzyıl ve sonrasında özellikle Avrupa'da oldukça revaçta olmakla birlikte Sanayi Devrimi sonrası endüstrideki makineleşmenin de etkisiyle birlikte sentetik boyaların üretilmesi sonucu zamanla unutulmaya yüz tutmuştur. Tanınırlığı ve bilinirliği oldukça kısıtlı olan Edirne Kırmızıs1, 2017 yılında yapılan bir araştırma sonrasında yeniden gündeme gelmiştir. Resmi kurumların yanı sıra sivil toplum kuruluşlarının ve yerel esnafın da harekete geçmesiyle birlikte Edirne Kırmızısı ile ilgili çok sayıda çalışma hayata geçirilmiş̧tir. Bu çalışmalar Edirne Kırmızısı'nı yeniden kent kimliğine kazandırma girişimlerini hızlandırmış ve rengin turizm faaliyetlerinde kullanılan bir obje haline dönüşmesine etki etmiştir.

$\mathrm{Bu}$ araştırmada, 2017 yılında mahalli bir gazetede yayımlanan yazı dizisi sonrası kent gündemine gelen Edirne Kırmızısı'nın Edirne kent kimliğine yeniden 
kazandırılarak markalanması ve destinasyon pazarlamasında rekabet gücü oluşturmasına zemin sağlayacak sonuçların elde edilmesi amaçlanmıştır. Edirne Kırmızısı'nın bilinirliliğini sağlayan çalışmaların tespitinde öncü olan bu araştırmanın Edirne ilinin kimliğine, tanıtımına, turizmine ve ekonomisine olan etkisinin ortaya konması ve gelecekte planlanacak faaliyetlere rehberlik etmesi de hedeflenmektir.

\section{KENT KIMLIIĞí VE EDIRNE İLININ TURIZM POTANSIYYELİ}

Kent kavramı, bir kentte yaşayan insanları çevreleyen ve etkileyen geniş bir kavram olmakla birlikte insanın davranış ve düşüncelerini de etkileyen farklı bir sosyal düzeni de ifade etmektedir (Kavruk, 2002: 65). Tarih boyunca birçok anlamla ifade edilen kent kavramı dinamik bir kavram olup sürekli geçerli olabilecek bir tanıma sahip olmamıştır (Koyuncu, 2011: 32). Kent sözcüğü tarih boyunca kavramsal olarak pek çok değişime uğramıştır. Geçmiş dönemde "cite", "medine", "polis" ve "kent" gibi birbiriyle ilintili olarak kullanılan kavramlar günümüzde "city", "ville", "bourg" ve "urban" gibi kelimelerle ifade edilmektedir (Topal, 2004: 277). Kent kimliği kavramı ise kentlerin kültürel, folklorik, sembolik kodlarıyla tıpkı bir insan gibi bir kimliği olduğu anlamı taşımaktadır. İnsanların kişilikleri, kimlikleri vardır ve insan toplulukları oldukları için şehirler vardır. Kent ruhu da insanlar ve yer arasındaki etkileşimlerden ortaya çıkan karmaşık kişilik olarak tanımlanabilmektedir (Landry ve Murray, 2017:2).

Bir kentin tarihi ve kültürel hafizasını yansıtan bir ifade olarak da tanımlanabilecek bir kavram olan kent kimliği, bir kente yüklenen soyut bir kavramdır ve bir kentin ayrıştırıcı özellikleri arasında gösterilmektedir. Bir kentin bir kimliğe sahip olması, kent sakinlerinin yaşadıkları kenti özümsemeleri ve sahiplenmeleriyle alakalıdır. Kent kimliği kısa sürede oluşan bir kavram değildir. Uzunca gözlemlenebilen bir süreci kapsamaktadır. Bir kentin kimliği tarihsel süreçle ilintili olmakla birlikte zaman içinde oluşur ve bu bağlamda değişim göstermektedir. Tarihi kentsel dokular, anılarla dolu olduğu için kuşaklar arasında manevi bir bağ kurmakta ve tarihi bilince kaynaklık etmektedir. Tarihi ve kültürel bir birikime sahip olan kentler farklı bileşenlerin de etkisiyle zamanla bir kimlik edinmektedirler. Bu kimlik, bir değişim içinde olan toplum ve insan ilişkilerinin yenilenmesini sağlamaktadır.

Kentlerdeki turizm hareketleri çok eskilere dayanmakla birlikte Mezopotamya'da Sümerlerden bu yana yaşanmaktadır (World Tourism Organization, 2012). Kentsel turizm, alternatif turizm türlerinden biri olmakla birlikte bir kentin sosyal ve kültürel hayatı hakkında bilgi edinmemizi sağlamaktadır. Bir kentin gelişmişlik düzeyi turistleri etkileyen önemli bir ölçüttür. Turizm hareketlerinin artmasına olumlu yönde etki eden kentsel gelişim, bir kentin alt yapı ve üst yapı özelliklerinin yanı sıra taşıdığı tarihi ve kültürel birikim ile alakalıdır. Kentlerin, tarihi, kültürel, doğal, coğrafi özellikleri de çeşitli turizm 
faaliyetleri ile ziyaretçilere sunulmaktadır. Kentsel yaşam, içinde birçok unsuru barındırmaktadır. Tarih, kültür, mimari, sportif faaliyetler, sanatsal etkinlikler, sosyal hayat, yeme içme gibi birçok unsur kentsel yaşamı oluşturmaktadır. Bir kentin mimarisi, gastronomisi, sanatsal ve kültürel etkinlikleri, tarihi birikimi ve kültürel yapısı, insanları kentsel turizm deneyimine yönlendirmektedir. Dolayısıyla kentsel turizmi diğer turizm çeşitlerinden ayıran özelliklerin başında, ziyaretçilere sunulan farklı ürün ve hizmetleri içermesi ve pek çok turizm türünü bünyesinde barındırma özelliği gelmektedir (Özer, Uca, 2010: 160). Kent turizmi ya da kentsel turizm son dönemde ilgi çekiciliği yeniden artan, turizmin en eski türlerinden biri olarak dikkat çekmektedir (İçellioğlu, 2014: 42). Kent turizmine olan ilginin artmasının nedeni, kentleri insanların yemek yediği, alışveriş yaptığı ve vakit geçirdiği kültür ve rahatlama merkezleri haline getiren davranışsal değişikliklerdir (European Commission, 2000).

Edirne ili, "kent kimliği" kavramının özelliklerini taşıyan şehirlerin başında gelmektedir. Çok sayıda savaş, göç ve mübadele olayına şahitlik eden Edirne ili, jeopolitik olarak önemli bir konumdadır. İki ülkeyle sınırı bulunan Edirne ili ayrıca UNESCO Kültür Mirası Listesi'nden somut ve somut olmayan eserlere sahiptir. Tüm bu özellikler Edirne iline kent kimliği unsuru kazandırmaktadır. Edirne ili, Cumhuriyetin ilk yıllarına kadar Türk ve Müslümanların yanı sıra Yahudiler, Ermeniler, Rumlar, Pomaklar, Bulgarlar, Romanlar gibi pek çok farklı dine ve millete mensup toplulukların bir arada yaşadığı bir şehir olmuştur. Şalom Gazetesi'nde yer alan "Mevcudu kalmamış bir Yahudi Cemaati: Edirne" başlıklı makalede 1943 yılında Edirne'de iki bin civarında Yahudi cemaatine mensup insanın yaşadığı belirtilmektedir (Besalel, 2015). Günümüzde Yunanistan ve Bulgaristan gibi Avrupa Birliği üyesi iki ülkeye sınır komşuluğu yapan Edirne ili, Asya ve Avrupa kıtaları arasında bir köprü görevi üstlenmektedir. Bu durum, Edirne ilini jeopolitik ve stratejik açıdan önemli bir konumlamaya dâhil etmektedir ve Edirne iline bir sınır kenti kimliği kazandırmaktadır. Osmanlı Devleti’ne uzun yıllar başkentlik yapması, kültürel boyutlu en eski spor organizasyonları arasında gösterilen Kırkpınar Yağlı Güreşlerine 6,5 asırdan fazla ev sahipliği yapması da Edirne ilinin kültürel kimliğini artırmaktadır.

Bir kentin kimliğinin oluşmasında kültürel bileşenler kadar doğal özellikler ve mimari yapılar da ön plana çıkmaktadır. İçinden üç nehrin geçmesi ve başta Osmanlı dönemine ait olmak üzere pek çok medeniyete ait tarihi ve mimari esere de ev sahipliği yapması Edirne ilinin kent kimliğine değer katan etkenlerdendir. Meriç, Tunca ve Arda nehirleri, İzzet Arseven Edirne Kent Ormanı, Sarayiçi'nde bulunan Tavuk Ormanı gibi doğal alanlar Edirne ilinin doğal kimlik elemanları arasında yer almaktadır. Kent kimliğinde somut bileşenlerin yanı sıra soyut bileşenler de belirleyici etkendir. UNESCO'nun Somut Olmayan Kültür Mirası Listesinde yer alan Tarihi Kırkpınar Yağlı Güreşleri de Edirne'nin kimliğini 
Aralık 2021 Cilt 23 Sayı 2 (941-962)

oluşturan kültürel bileşenlerden biridir. Öte yandan bir kentteki türküler, halk dili, bu halk dilinde kullanılan şive, birtakım inanışlar ve gelenekler de kent kimliğinin oluşmasına büyük katkılar sağlamaktadır. Trakya ve Balkanlar coğrafyası için geçmişten günümüze önemini yitirmeyen Edirne'de yerel halkın " $h$ " harflerini söylememesi, günlük konuşma diline bazı kelimeler eklemesi ve kendine özgü bir aksan oluşturmasını da Edirne'nin kent kimliğinin yansımaları olarak gösterilebilir.

\section{RENK KAVRAMI VE EDİRNE KIRMIZISI}

Renk kavramı üzerine birçok tanımlama yapmak mümkündür. Teknik bir ifadeyle renk; 1şı̆̆ın, kendi öz yapısına veya cisimler tarafından yayılma şekline bağlı olarak göz üzerinde yaptığı etkidir (Meydan Larousse, 1992: 486). Renk isimleri dilden dile farklılık gösterse de görünüşleri dünyanın her yerinde aynıdır. Renklerin ifade ettiği anlamlar ise kişiden kişiye değişmektedir ve kültürel anlamda da yapılarda farklılık gösterebilmektedir. Aynı zamanda renklerin insanlar üzerinde psikolojik bir etkisi olduğu gerçektir. Her ne kadar kültürler arasında farklılık gösterse de renkler kısaca ışığın fizyolojimize yaptığı etki bakımından psikolojik olarak bir algı oluşturmaktadır. Her millet kendi anlamını belirlediği renkleri birtakım semboller ile birleştirmiştir (Dokumacı, 2020: 122). Renklere ilişkin farklı bakış açılarının oluşmasında ırk, coğrafya, iklim şartları, yaşam tarzları, ekonomik şartlar, siyaset, düşünce ve inanç gibi pek çok faktörün etkisi vardır (Eren, 2008: 32). Geçmişten günümüze aşk ile en çok bağdaştırılan kırmızı rengi gücü, neşeyi, mutluluğu ifade etmekte ve kullanıldığı ortamda dinamik bir etki oluşturmaktadır. Tarih boyunca pek çok alanda farklı yöntemlerle kullanılan kırmızı rengi, güneşin ve tüm savaş tanrılarının rengi olarak adlandırılmış ve ateşi, hükümdarlığı, aşkı, hazzı ifade etmiştir (Çoruhlu, 2000: 191).

"Kırmızı" sözcüğü kelime kökeni olarak, Arapçada "kırmız" adıyla bilinen ve kırmızı renkte boya veren bir böceğin adından türemiştir. Osmanlı Türkçesinde aynı rengi ifade etmek için Farsça kökenli "sürh", Arapça kökenli "ahmer" ve Türkçe kökenli "al" ve "kızıl" sözcükleri de kullanılmıştır (Demir, 2015: 61). Ögel (1948), Türklerin "kırmızı" kelimesini Orta Çă̆'dan itibaren kullanmaya başladığını, kırmızı yerine daha çok "kızıl" kelimesini tercih ettiklerini belirtmektedir.

Bilinen en eski renklerden biri olan kırmızıya ilk kez mağara resimlerinde rastlanılmaktadır. MÖ 15.000 ile 16.500 yıllarında Altamira mağarası ve İspanya'daki tarih öncesi mağara resimleri, aşıboyası ile yapılan resimlerin en erken örneklerinde kırmızı rengine rastlanılmaktadır (Çağlar, 2019). Tarihçi ve Araştırmacı Dominique Cardon (1995: 72), "Olabildiğince Kırmızi: Sonsuz Kırmızısı Arzusu Karşısında Boyamacının Sanatı” başlıklı makalesinde kırmızı renginden, "11. yüzyılda Eski Kahire'de bir tüccar boyamacısına 'Bayım sizden istirham ediyorum, kırmızı olabildiğince kırmızı olsun’ diye yazıyordu. Kırmızı ve 
yoğun kırmızı arzusu yeni değil: tarih öncesinden günümüze ulaşan kumaşlar üzerinde hala seçilebilen renkler sıklıkla kırmızıdır." şeklinde bahsetmektedir.

Kırmızı rengi, yeni yıl için de sembolik bir anlam taşımaktadır. Örneğin, Çinliler yılbaşını Ekim ayında kutlamaktadırlar. Çin geleneğinde Nian (yıl) adlı bir canavarı korkutmak için kırmızıya boyanmış bambu dalları ve kâğıtlar yakılmaktadır. Böylece eski yılın kaçtığına ve yeni yılın geldiğine inanılmaktadır. Batı kültüründe ise kırmızı; uyarı, öfke ve ateşle ilişkilendirilmiştir. Ateşe karşılık gelen kırmızının bir türü de, Çin kırmızısı olarak da bilinen ve zincifre mineralinden üretilen "vermilyon" "dur. Neşeyi ve iyi şansı sembolize eden kırmızı, astrolojide ise Çin takımyıldızlarının dört simgesinden biri olan ve alevlerle kaplı kırmızı bir kuş olarak tanımlanan "Vermilyon Kuşu" "ile temsil edilmektedir.

Kırmızının parlak bir tonu olan vermilyon, Orta Çağ'da en lüks keten örtülerin boyamasında kullanılmıştır. Bu tonla çoğu zaman karıştırılan ve adını Ermenistan kırmızböceğinden ve etimolojik olarak "kirmiz" kelimesinden alan "cramoisi" kırmızısı da hala günümüzde bilinmektedir. Neredeyse morlaşmış derin bir kırmızı olan "cramoisi" tonu, Cenova, Venedik ve Bursa kadifelerinde kullanılmıştır (Cardon, 1995: 72).

Kırmızı rengi birçok sektörde kullanılmakta olup kullanım alanına ve tonuna göre farklı isimlerle adlandırılmıştır. Alizarin rengi, horozibiği rengi, kiraz rengi, mercan kırmızısı, Hollywood kiraz rengi, nar rengi, kırmızı menekşe rengi, Venedik kırmızısı, Vermilion, İran kırmızısı, Karmen kırmızısı, Falu kırmızısı, kan kırmızısı, berry, scarlet, yakut kırmızı, tuğla kırmızısı, domates kırmızısı, vişne kırmızıs1, crimson, ruj kırmızısı, terracotta, Kongo kırmızıs1 ve burgundy, farklı isimlerle anılan kırmızı tonlarına örnek olarak gösterilebilir.

\section{EDİRNE KIRMIZISI}

Türkler tarafından renk alan yazınına kazandırılan ve tüm dünyada bilinen iki renk vardır: Biri turkuaz diğer ise (Turkey Red) Türk Kırmızısı'dır. Türk Kırmızıs1, Edirne Kırmızıs1 olarak da bilinir (Eng: Andrinople Red, Fr: Rouge d'Andrinople). 19. yüzyıla ait numune kitaplarında "Türk Kırmızısı" ve "Edirne Kırmızısı" terimleri aynı anda belirmektedir. Avrupa'da ilk başta Türk Kırmızısı adıyla bilinen Edirne Kırmızısı, boyacılarıyla meşhur Edirne'den iki boyacının Fransa'ya götürülmesi sonucu önce Avrupa'da, sonra tüm dünyada büyük bir üne ulaşmıştır (Yıldırım, 2014: 16-17). Özellikle 18. ve 19. yüzyıllarda Avrupa tekstil piyasasının en önemli figürlerinden biri haline gelen Edirne Kırmızısı, gizemini usta çırak öğretisine dayalı olarak uzun yıllar korumayı başarmıştır. Tekstil sektöründe, daha çok pamuklu ve ipek kumaşların boyamasında kullanılan kırmızı

\footnotetext{
1 "Vermilyon” https://tr.wikipedia.org/wiki/Vermilyon (Erişim Tarihi: 20.05.2021).

2 "Vermilyon Kuşu" https://tr.wikipedia.org/wiki/Vermilyon_Ku\%C5\%9Fu (Erişim Tarihi: 20.05.2021).
} 
Aralık 2021 Cilt 23 Sayı 2 (941-962)

rengin bir tonu olan Edirne Kırmızısı, disiplinler arası bir kavram olup ziraattan kimyaya, tekstilden modaya pek çok alanı içine çekmektedir. Uzun, karmaşık ve bir sır gibi saklanan Edirne Kırmızısı aslında pamuk boyama tekniğinden ibarettir. $\mathrm{Bu}$ teknik, pamuklu kumaş tuvali yağlama gibi birçok işlem sonucundan oluşmaktadır (Jacque, 1995: 10).

Yürek'e (2021: 59) göre kırmızı rengi aşkın, tutkunun, aynı zamanda gücün rengidir ve Edirne de tarih ve kültür açısından güçlü bir şehirdir. Edirne Kırmızısı da bu gücün simgesidir. 1993-94 yılları arasında Fransa'nın Mulhouse kentindeki sergiden esinlenerek Fransizca yazılan "Adnrinople: Le Rouge Magnifique", "Muhteşem Edirne Kırmızısı" diye çevrilse de Fransızcadaki anlamı "Edirne: Muhteşem Kırmızı" diye geçmektedir. Bu durum, Edirne Kırmızısı'nın Edirne'ye ait bir renk olarak değil de Edirne'nin kendi başına bir renk olarak görüldüğü görüşünü ön plana çıkarmaktadır. Bazı Fransız kaynaklarında "Andrinople (Edirne)" kelimesinin "kırmızının bir tonu" diye açıklanması ve "Adnrinople: Le Rouge Magnifique" kitabında "Edirne rengi" ifadesinin kullanılması da bu görüşü desteklemektedir.

19. yüzyılda yaşayan İskoç bilim insanı, doktor ve kimyager Andrew Ure (1844: 793) rengi "bilinen en hızlı renk" olarak yorumlamaktadır. Julie Wertz ise Türk Kırmızııı'nı bir "boyama sanatındaki en karmaşık ve meşakkatli operasyon" olarak tanımlamaktadır. Tekstil sektöründe, daha çok pamuklu ve ipek kumaşların boyamasında kullanılan kırmızının bir tonu olan Edirne Kırmızısı, oldukça zorlu ve uzun bir süreç sonrası elde edilmektedir. Pamuğun Rubia tinctorum L. olarak da bilinen kök boya ile 38 basamaklı yüksek değer ve renk tonundaki boyaması olarak bilinen Türk Kırmızısı veya Edirne Kırmızısı boyaması usta çırak öğretisine dayalı olarak gizemini ve gizliliğini uzun yıllar korumuştur (Karadağ, 2007). Edirne Kırmızıs1, kumaş baskılarında farklılık göstermektedir. "Adnrinople: Le Rouge Magnifique" kitabının editörü Jacqueline Jacque, Wescher'e dayandırdığı bilgiye göre bu durumu; "Avrupa'daki belli başlı boyama merkezleri üzerine 1860 tarihli bir rapora göre, Alsace yoğun kiraz ve kadifemsi bir kırmızı, İsviçre Ponceau'nun sarımsı tonunu yansıtan bir kırmızı, İngiltere hafif kahverengi bir ton kırmızı, Rouen ise Türk Kırmızısı'na çok yaklaşan daha yoğun bir kırmızı üretir.” şeklinde açıklamaktadır.

\section{EDIRNE KIRMIZISI'NIN KENT KIMLİĞİNE KAZANDIRILMASI ADINA GÜNÜMÜZE KADAR YAPILAN ÇALIŞMALAR}

Edirne Kırmızısı'nın kamuoyunda yeniden gündeme gelmesi, Edirne'de günlük olarak yayımlanan yerel bir gazete olan Hudut Gazetesi'nde yer alan bir yazı dizisine dayanmaktadır. 20-21 ve 22 Mart 2017 tarihlerinde "Paylaşllamayan Kırmızı" başlığıyla yayımlanan yazı dizisi sonrası Edirne kamuoyu "Edirne Kırmızısı" ile tanışmıştır. Edirne'de oldukça ses getiren yazı dizisiyle birlikte Edirne Kırmızısı sonrası Edirne ilindeki resmi kurum ve kuruluşların yanı sıra sivil 
toplum örgütleri tarafından hayata geçirilen çalışmalarla Edirne Kırmızısı'nın bilinirliği artmış ve renk daha geniş kitleler tarafından tanınmıştır.

Edirne Kırmızısı'nın kent kimliğine ve turizme kazandırılması adına özellikle Trakya Üniversitesi'nin önemli çalışmaları olmuştur. Rengin kent kimliğine kazandırılması için 2020 ve 2021 yıllarını kapsayan "Edirne Kırmızısı Stratejik Planı" oluşturan Trakya Üniversitesi, bu plan doğrultusunda birçok çalışmayı hayata geçirmiş ve halen projeler üretmeye devam etmektedir. Akademisyen ve araştırmacılar tarafından oluşturulan "Edirne Kırmızısı Stratejik Planı" dâhilinde beş ana başlıkta toplanan çalışmalar çeşitli alt gruplara ayrılmıştır. Farklı disiplinleri kapsayan stratejik plan, "Bilimsel ve Akademik Çalışmalar", "Kültürel ve Sanatsal Çalışmalar", "Tarih ve Araştırma Çalışmaları", "Ticari ve Yerel Ekonomiye Katkı Çalışmaları" ve "Diğer Çalışmalar" başlıklarından oluşmaktadır. Trakya Üniversitesi tarafından Edirne Kırmızısı ile ilgili yürütülen proje ve çalışmalar şu şekildedir:

1) "Andrinople: Le Rouge Magnifique" İsimli Kitabın Trakya Üniversitesi Kütüphanesine Kazandırılması (2017)

2) 1. Uluslararas1 Edirne Kirmızıs1 e-Sempozyumu (2020)

3) Rubia tinctorum L. Kök Boya Bitkisinin Yetiştirilmesi Projesi (2020)

4) Edirne Kırmızısı İnternet Sitesi (2020)

5) Edirne Kırmızısı Logo Tasarım Yarışması (2020)

6) Edirne Kırmızısı Kumaş Koleksiyonu (2021)

7) "2. Uluslararası Kültür, Sanat ve Edebiyat Kongresi” (2021) (2021)

8) "Edirne Kırmızısı'nın Kent Kültüründeki Yeri ve Önemi" Semineri

9) "Reng-i Edirne" Markas1 (2020)

10) "Edirne Kırmızısı" Tez Kapağı Uygulaması (2021)

11) Diğer Çalışmalar

Edirne Kırmızısı'nın kent gündemine gelmesiyle birlikte atılan ilk somut adımlardan biri, Fransızca yazılan "Andrinople: Le Rouge Magnifique" isimli kitabın Trakya Üniversitesi Merkez Kütüphanesi’ne kazandırılmasıdır. Trakya Üniversitesi Kütüphane Dokümantasyon Daire Başkanı Recep Zogo'nun girişimleri sonucu kitap, yurt dışından getirtilerek 2017 yılı Kasım ayında Trakya Üniversitesi'nin “Edirne Kitaplı̆̆ı" dökümüne 550. kitap olarak kayıt edilmiştir.

Edirne Kırmızısı Stratejik Eylem Planının "Bilimsel ve Akademik Çalışmalar” başlığının bir alt çalışması olan "1. Uluslararası Edirne Kırmızısı eSempozyumu" 20 Ekim 2020 tarihinde Trakya Üniversitesi ev sahipliğinde çevrim içi olarak düzenlenmiştir. Türkiye, Romanya ve Yunanistan'dan akademisyen ve araştırmacıların katılımıyla iki ayrı oturumda gerçekleşen sempozyumda Edirne Kırmızısı bilimsel açıdan değerlendirilmiştir. Edirne Kırmızısı renginin kentin markalanmasında önemli bir etken olduğunun vurgulandığı sempozyumda Edirne 
Aralı 2021 Cilt 23 Say 2 (941-962)

Kırmızısı Müzesi ve Edirne Kırmızısı Sokağı gibi öneriler dile getirilmiştir. Sempozyumda ayrıca Edirne Kırmızısı'na rengini veren doğal kökboyanın gıda, kozmetik, eczacılık, nano-teknoloji gibi birçok alanda kullanımının yaygınlaştırılabileceği belirtilmiştir. Sempozyumdaki sunum ve bildiriler daha sonra bir kitapta toplanarak üniversite kütüphanesine kazandırılmıştır.

"Bilimsel ve Akademik Çalışmalar" başlığının bir diğer projesi, Edirne Kırmızısı üretiminde kullanılan bir kök boya bitkisi olan Rubia tinctorum L.'nin yetiştirilerek çoğaltılması adına başlatılan girişimler olmuştur. Havsa Meslek Yüksekokulu Müdürü Prof. Dr. Mustafa Tan öncülüğünde, Park ve Bahçe Bitkileri Bölümü'nden Dr. Öğr. Üyesi Sedat Karadavut ve Öğr. Gör. Adnan Çolak tarafından hazırlanan "Edirne Şartlarında Doğal Boya Bitkisi Kök Boyanın (Rubia tinctorum L.) Tarımsal Potansiyelinin Belirlenmesi" isimli proje dâhilinde Havsa Meslek Yüksekokulu'na ait bir alana 1000 adet Rubia tinctorum L. bitki kökü ekilmiştir. Edirne'de bulunan yerel popülasyonlar ile İran'dan getirtilen iki ayrı popülasyonun verim ve boya madde oranının Trakya'daki iklim ve toprak koşulları göz önünde bulundurularak araştırıldığı proje kapsamında ekilen kökler üç ay boyunca incelenmiştir. Proje kapsamında ayrıca kök bitkisinin, Edirne ili topraklarında tarımsal gelişme potansiyelinin ortaya konması ve üreticiler için alternatif bir ürün oluşturulması amaçlanmıştır. Projenin bir çıktısı olarak Trakya Üniversitesi Balkan Yerleşkesi içerisinde "Kök Boya Gen Bahçesi” oluşturulmuş ve Havsa'da yetiştirilen Edirne kökenli üç genotip ile İran kaynaklı iki genotipten oluşan 200 adet fide, bahçeye ekilmiştir. Yapılan bu girişimlerle birlikte Edirne'deki çiftçi ve üreticilerin yanı sıra genç girişimcilerin de ilgisinin Rubia tinctorum L. bitkisine yöneldiği gözlenmiştir.

Edirne Kırmızısı'nı kurumsal bir zemine taşımak amacıyla 6 Kasım-18 Aralık 2020 tarihleri arasında "Edirne Kırmızısı Logo Tasarım Yarışması" düzenlenmiştir. Yarışmaya 400'den fazla eser sahibi 703 çalışma ile başvurmuştur. Genel sunum, temaya bağlılık, özgünlük, estetik değer, renk uyumu ve eserin kompozisyonu parametrelerini esas alındığ 1 yarışmanın birincisi, Özkan Keçili'ye ait tasarım olmuştur. Yarışmada sergilenmeye değer 30 eser çevrim içi bir sergi ile dijital ortama aktarılmıştır.

Edirne Kırmızısı'nı somutlaştırmak adına girişimlerden biri de, hazır giyimde Türkiye'nin önemli markalarından biri olan Kiğılı ile imzalanan protokol kapsamında oluşturulan ipek ve polyester kumaşlardan oluşan bir koleksiyon olmuştur. Şal, kravat ve mendilden oluşan koleksiyonun ilk parçası kent genelinde ilgiyle karşılanmıştır. Trakya Üniversitesi ve Kiğılı firmasının tekstil ürünlerinde başlattığı iş birliği akademik ortama da taşınmıştır. İki kurum temsilcileri tarafından hazırlanan "Edirne Kırmızısı'nın Çağdaş Yaklaşımlarla Tekstil Desen Çalışmalarında Kullanımı" başlıklı makale, 2. Uluslararası Kültür, Sanat ve Edebiyat Kongresinde yayımlanmıştır. Türkiye'nin yanı sıra İtalya, Hindistan, 
Azerbaycan, Filipinler, İran, Pakistan ve Kazakistan'dan akademisyen ve araştırmacıların katılımıyla gerçekleşen kongrede Edirne Kırmızısı'nın tarihi, önemi ve tekstil desenlerinde kullanımı aktarılmıştır.

Trakya Üniversitesi Sosyal Bilimler Enstitüsü, yüksek lisans ve doktora öğrencilerinin tezleri için Edirne Kırmızısı temalı kapaklar hazırlatmıştır. Trakya Üniversitesi senatosuna sunulan öneri sonrası Temmuz 2021 y1lı itibariyle yüksek lisans ve doktora tezlerini tamamlayan öğrenciler tez kapaklarını, Edirne Kırmızısı renginin kullanıldığı bir tasarımla Sosyal Bilimler Enstitüsü'ne teslim etmişlerdir.

Trakya Üniversitesi tarafından yürütülen çalışmalardan biri de Edirne Kırmızısı'nın "Reng-i Edirne" ismi ile markalanması çalışması olmuştur. 5 Şubat 2021 tarihinde 2021/19255 numaralı başvuruda 13 sınıfta rengin markalaşması sağlanmıştır. Ayrıca Trakya Üniversitesi tarafından Edirne Kırmızısı ile ilgili hayata geçirilen çalışma ve faaliyetlerin kamuoyuna duyurulması için 2020 y1lı Ekim ayında "www.edirnekirmizisi.trakya.edu.tr" internet sitesi kurulmuştur.

Kamuoyunu bilgilendirmek amaciyla Trakya Üniversitesi tarafindan her ay yayımlanan "Trakya Kampüs" gazetesi, 12. sayısını "Edirne Kırmızısı"na ayırmıştır. Trakya Üniversitesi Basın Halkla İlişsiler Birimi tarafından yayına hazırlanan gazetenin Mart sayısında Edirne Kırmızısı'nın kent kimliğine kazandırılması adına Trakya Üniversitesi tarafından yapılan çalışmalar aktarılmıştır.

Diğer yandan Trakya Üniversitesi Edirne Uygulama ve Araştırma Merkezi tarafindan "Kent Söyleşileri”" başlığı altında düzenlenen çevrim içi söyleşilerinde Edirne Kırmızısı'na yer verilmiş olup “Edirne Kırmızısı'nın Kent Kültüründeki Yeri ve Önemi” başlıklı bir seminer düzenlenmiştir. Ayrıca Trakya Üniversitesi Rektörlüğü tarafından Yüksek Öğretim Kurumu tarafından dört ayrı kategoride düzenlenen YÖK Üstün Başarı Ödüllerinin "Yerel Kalkınmaya Katkı Ödülü" kategorisine "Edirne Kırmızısı'nın Kent Kimliğine, Turizme ve Kent Ekonomisine Kazandırılması" projesi ile başvurulmuştur.

Trakya Üniversitesi tarafindan gerçekleştirilen çalışmalara ilaveten Edirne Valiliği İl Kültür ve Turizm Müdürlüğü, Edirne Belediyesi, Trakya Tarımsal Araştırma Enstitüsü, Kırklareli Olgunlaşma Enstitüsü, Edirne Tanıtım ve Turizm Derneği gibi resmi kurum ve kuruluşlar ile sivil toplum kuruluşlarının yanı sıra yerel esnaf da Edirne Kırmızısı ile ilgili çalışmalar yürütülmüş̧ür. Bu çalışmalar şu şekildedir:

1) "Edirne’yi Keşfet”" Etkinliği (Edirne Belediyesi-2017)

2) Edirne Kırmızısı Çalıştayı (Edirne Tanıtım ve Turizm Derneği-2018)

3) Tekstil Firmaları ile Edirne Kırmızısı Buluşması (Edirne Tanıtım ve Turizm Derneği-2018)

4) Mulhouse Kentine "Edirne Kırmızısı" Ziyareti (Edirne Tanıtım ve Turizm Derneği-2018) 
Trakya Üniversitesi Sosyal Bilimler Dergisi

Aralık 2021 Cilt 23 Sayı 2 (941-962)

5) Yerel Tarih Grubuna "Edirne Kırmızısı" Sunumu (Edirne Tanıtım ve Turizm Derneği-2019)

6) "Çargâh Makamı: Edirne Kırmızısının Hikâyesi" Tiyatro Gösterisi (İl Kültür ve Turizm Müdürlüğü-2019)

7) Edirne Kırmızısı Renginde Boyanan Konak (Yerel Girişim-2019)

8) İşletmelerde Edirne Kırmızısı Önlüğü (Yerel Girişim-2019)

9) Kırklareli Olgunlaşma Enstitüsünün Çalışmaları (2019-2020)

10) "Edirne Kırmızısı" Romanı (Yerel Girişim-2021)

11) Uluslararası Sinırsız Dostluk Yar1 Maratonu'nda Edirne Kırmızıs1 Temas1 (Türk-Yunan-Bulgar Dostluk Grubu Derneği-2021)

\section{AMAC VE YÖNTEM}

Araştırmanın amac1, Edirne ilinde 2017 yılından itibaren Edirne Kırmızısı ile ilgili hayata geçirilen çalışmaların bir araya getirilmesi ve bu çalışmaların Edirne ilinin kent kimliğine ve turizmine olan etkisini ölçmektir. Edirne Kırmızısı ile ilgili yapılan çalışmaların envanterinin çıkarıldığı bu araştırmada kültürel bir miras ve turistik bir ürün olarak Edirne Kırmızısı'nın kentin tanıtımına ve turizmine nasıl katkı sağlayabileceğinin ortaya koyulması amaçlamıştır. Renk konusunda yeni bir imaj yaratma gereksinimine ihtiyacın duyulmadığı Edirne ilinin kültürel değeri ve turistik bir objesi olan Edirne Kırmızısı renginin bilinirliğinin kısıtlı olması, bu çalışmanın yapılması gerekliliğini doğurmuş ve çalışmayı önemli bir hale getirmiştir.

Nitel araştırma yöntemlerinin kullanıldığı çalışmada Edirne ilinde kent kimliği ve kentsel turizm kavramlarının gelişmesinde ve geliştirilmesinde yetkisi olan, Edirne Kırmızısı ile ilgili yapılan çalışmalara aktif rol alan ve ileride yapılacak çalışmalara katkı sağlayacağı düşünülen katılımcılar belirlenmiştir. Araştırmanın evrenini Edirne Kırmızısı ile ilgili çalışma ve faaliyet gerçekleştiren kurum ve kuruluşların temsilcileri oluşturmuştur. Edirne Kırmızısı ile verilerin kısıtlı̆̆ nedeniyle araştırmanın örneklemini, renk hakkında bilgi sahibi olan kişiler oluşturmaktadır. Yerel yöneticiler, akademisyenler, sivil toplum kuruluşu temsilcileri, basın mensupları esnaf ve özel sektör çalışanları olmak üzere toplam 20 kişiyle görüşmelerin yapıldığı bu çalışmada araştırmanın amacı doğrultusunda soruların yönetildiği kişiler, yeterli cevapların alınacağı öngörülerek titizlikle tespit edilmiştir. Edirne Kırmızısı ile ilgili çalışmalar yapan ve gelecekte yapılacak faaliyetlerde görev alması muhtemel görülen kurum, kuruluş ve organizasyon temsilcileri de tespit edilerek bu araştırmaya dâhil edilmiştir.

Araştırmada katılımcılara açık uçlu sorular yöneltilmiştir. Ön araştırma yapılarak hazırlanan araştırma soruları, çalışmanın daha iyi anlaşılabilmesi adına çeşitli örneklerle sorulmuştur. Her bir görüşme 12 ila 43 dakika arasında gerçekleşmiştir. Yüz yüze ve çevrim içi yapılan görüşmeler katılımcıların izni doğrultusunda kayıt altına alınmış ve alınan cevaplar, katılımcıların görüşlerini 
yansıtan alıntılar ile desteklenerek Edirne Kırmızısı'nın bilinirliği ve ürün bazında çeşitlendirilmesi ölçülmüştür. Ayrıca Edirne Kırmızısı ile ilgili yapılan çalışmaların yeterli olup olmadığı ve Edirne Kırmızısı'nın kullanım alanları ile ilgili gelecekteki olumlu ve olumsuz tahminler değerlendirilmiştir. Toplanan veriler daha sonra MAXQDA 2020 nitel veri analiz programında analiz edilmiştir.

$\mathrm{Bu}$ araştırmada görüşlerine başvurulan katılımcıların Edirne Kırmızısı ile ilgili sorulara gerçekçi bir şekilde cevap vereceği düşünülmüştür. Ayrıca araştırmada katılımcıların araştırma evrenini temsil edecek düzeyde olduğu ve soruları kendi doğru bir şekilde algılayıp hür iradeleriyle cevaplayacakları varsayılmıştır. Araştırmanın yapıldığı sürecin küresel salgın dönemine denk gelmesi nedeniyle belirli sayıda kişiyle görüşme yapılmıştır. Salgın kapsamında uygulanan birtakım kısıtlamalardan dolayı görüşmelerin büyük bir bölümü internet üzerinden çevrim içi olarak gerçekleştirilmiştir. Araştırmada, Edirne'de yaşayan ve görev yapan katılımcılardan görüş alındığ 1 için elde edilen veriler Edirne ilini kapsamaktadır. Yapılan alanyazın ve arşiv taramalarında Edirne Kırmızısı ile ilgili yapılan araştırma ve çalışmaların az sayıda olması, ayrıca bazı yerli ve yabancı kaynaklarda Edirne Kırmızısı'nın Türk Kırmızısı olarak anılması, konu hakkında bilgi sahibi olan katılımcılara ulaşmayı zorlaştırmıştır. Araştırmaya konu olan Edirne Kırmızısı'nın üretim aşamasının uzun ve zorlu bir süreçten geçmesi ve bu kapsamda somut anlamda üretilen objelerin yetersizliği de araştırmanın sinırlılıkları arasındadır.

\section{ARASTTIRMANIN BULGULARI}

Araştırma bulgularına göre Edirne Kırmızısı ile ilgili yapılan çeşitli çalışmalar tespit edilmiş ve bu konuda paydaşların görüşleri alınarak görüşmeler analiz edilmiş ve değerlendirilmiştir. Araştırmaya katılan kişilerle yapılan görüşmelerden elde edilen veriler doğrultusunda ortaya çıkan bulgular analiz sonuçlarına göre yorumlanmıştır. Araştırmanın amacı doğrultusunda elde edilen bulgular gerekli yerlerde katılımcıların görüşlerini yansıtan doğrudan alıntılar ile desteklenerek sunulmuştur.

\subsection{Edirne Kırmızısı'nın İlk Ne Zaman Duyulduğuna Dair Bulgular}

Araştırmada, katılımcılara "Edirne Kırmızısı'nı ilk ne zaman duydunuz?" sorusu yöneltilerek rengin 2017 yılında mahalli bir gazetede yayımlanan yazısı dizisi ile bilinirliğinin artıp artmadığı ölçülmüsstür. Edirne Kırmızısı'nın ilk ne zaman duyulduğuna dair beş cevap ortaya çıkmıştır Verilerin yüzdesi Grafik 1'de gösterilmiştir. 


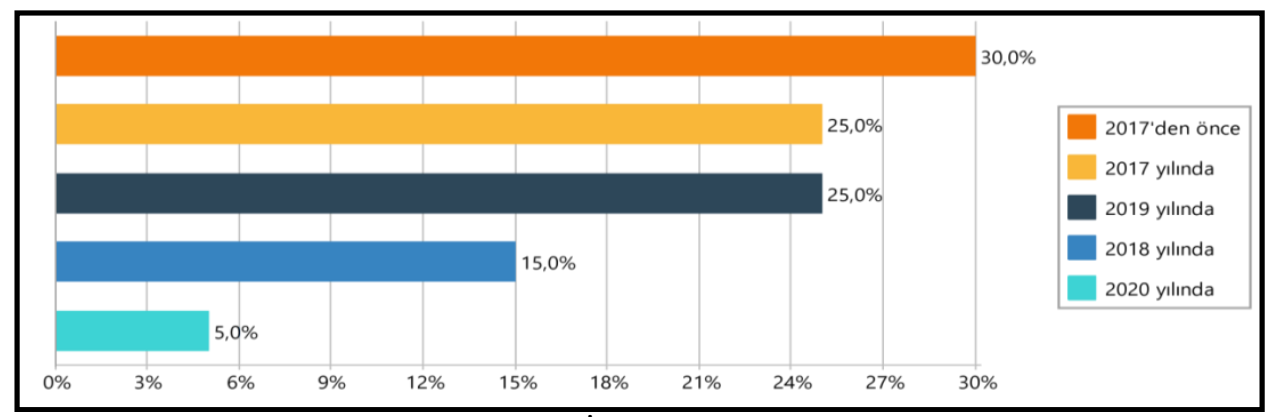
Yüzdeleri

Grafik1: Edirne Kırmızısı'nın İlk Ne Zaman Duyulduğuna Dair Cevapların

Cevaplara bakıldığında "2017'den önce" cevabını veren katılımcı oranı \%30 $(\mathrm{n}=6)$ olmuştur. "2017 y1lında" cevab1 veren katılımc1 oran1 \%25 (n=5), "2018 yılında" cevabi veren katılımc1 oranı \%15 (n=3), "2019 y1lında" cevabinı veren katılımc1 oran1 \%25 $(\mathrm{n}=5)$ ve "2020 y1lında" cevabinı veren katılıme1 oranı ise $\% 5$ $(\mathrm{n}=1)$ olmuştur. Araştırmada ayrıca beş kadın katılımcıdan üçü Edirne Kırmızısı'nı ilk kez 2019 yılında duyduğunu belirtmiştir. Edirne Kırmızısı'nın 2017 yılından önce sınırlı sayıda tarihçi, araştırmacı ve konuya özel ilgi duyan akademisyenler tarafından bilindiği sonucuna ulaşmıştır. Alınan cevaplar, katılımcılardan \% 70 'inin (n=14) Edirne Kırmızısı'nı 2017 yılı ve sonrasında duyduğunu göstermektedir. Bu oran, “Edirne Kırmızısı'nın 2017 yılından sonra bilinirliliğinin artığı” iddiasını desteklemektedir ancak kent genelini yansitmamaktadır.

\section{Bulgular}

6.2. Edirne Kırmızısı'nın İlk Hangi Kaynaktan Duyulduğuna Dair

Katılımcılara "Edirne Kırmızısı'nı ilk nereden duydunuz?" sorusu yöneltilerek rengin ilk hangi kaynaktan duyulduğu ölçülmüştür. Edirne Kırmızısı'nın ilk nerede duyulduğuna dair altı cevap ortaya çıkmıştır. Ortaya çıkan cevaplar incelendiğinde "mesleki proje ve toplantılar sayesinde" cevabını veren katılımc1 oranı \%30 (n=6) olmuştur. "Gazete aracılı̆̆ıyla" ve "bilimsel çalıma esnasında" cevabını veren katılımcı oranları \%20 (n=4), "Trakya Üniversitesi sayesinde" cevabını veren katılımc1 oran $1(\% 15(\mathrm{n}=3)$, "sosyal medya sayesinde" cevabinı veren katılımcı oranı $\% 10(\mathrm{n}=2)$, "halk arasında" cevabını veren katılımc1 oranı ise $\% 5(n=1)$ olmuştur.

Araştırmanın bu bölümünde toplanan veriler, 2017 yılında mahalli bir gazetede yer alan yazı dizisi sonrası yeniden kent gündemine gelen Edirne Kırmızısı'nın birtakım mesleki proje ve toplantılara, bilimsel çalışmalara ve çeşitli iletişim araçlarına konu olduğunu, Trakya Üniversitesi'nin bu konuda yaptığı çalışmalar da Edirne Kırmızısı'nın bilinirliğine katkıda bulunduğunu göstermektedir. Araştırmaya katılanların \%25'inin $(n=5)$ akademisyen olması da Trakya Üniversitesi'nin Edirne Kırmızısı ile ilgili etkinliğini ortaya koymaktadır. 


\subsection{Edirne Kırmızısı'nın Ne İfade Ettiğine Dair Bulgular}

Edirne Kırmızısı'nın neyi çağrıştırdığını tespit edebilmek adına katılımcılara "Edirne Kırmızısı sizin için ne ifade ediyor?" sorusu yöneltilmiştir. Verilen cevaplar sonucu yedi tema ortaya çıkmıştır (Grafik 2).

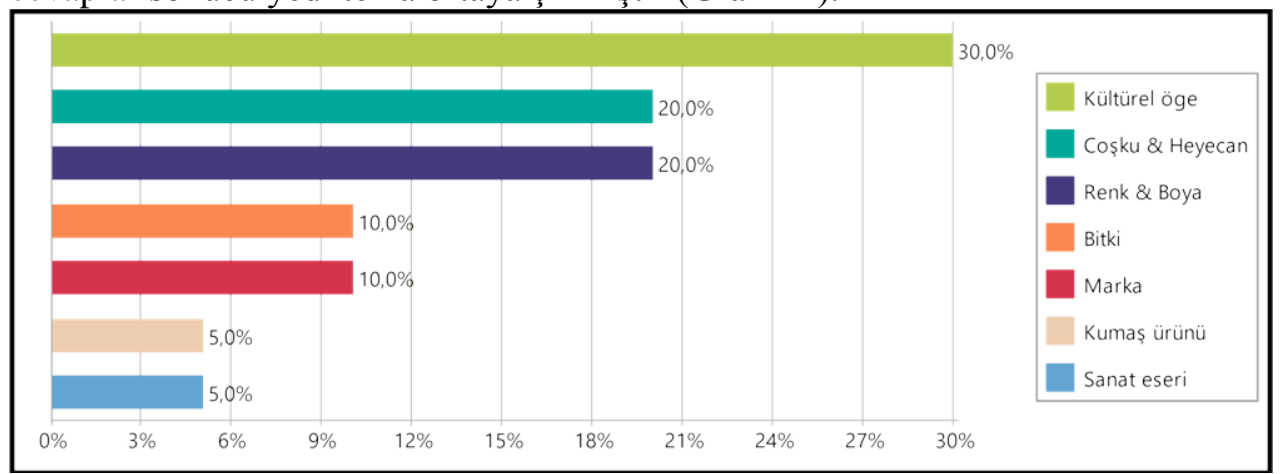

Grafik 2: Edirne Kırmızısı'nın Ne İfade Ettiğine Dair Cevapların Yüzdesi

Araştırmada bu kısmında Edirne Kırmızısı'nın "kültürel öge" temasını ifade ettiğini belirten katılımcı oranı \%30 (n=6) olmuştur. Edirne Kırmızısı'nın "coşku ve heyecan" uyandırdığını ve Edirne Kırmızısı'nın "renk ve boya” temasını ifade ettiğini belirten katılımcı oranları $(\% 20(n=4)$ olmuştur. Edirne Kırmızısı'nın "bitki" ve "marka" temalarını ifade ettiği cevabını veren katılımeı oranları \%10 $(\mathrm{n}=2)$, "kumaş ürünü" ve "sanat eseri”" temalarını ifade ettiği cevabını veren katılımc1 oranları ise $\% 5(\mathrm{n}=1)$ olmuştur.

$\mathrm{Bu}$ kısımda toplanan veriler, Edirne Kırmızısı'nın birden fazla kavramı kapsadığını ortaya koymaktadır. 20 katılımcının yedi ayrı başlık altında yanıt vermesi, Edirne Kırmızısı'nın sadece bir renk olarak değil, somut ve soyut kavramları da temsil ettiğini yansıtmaktadır. Özellikle katılımcıların \%30'unun Edirne Kırmızısı'nı kültürel bir öge olarak belirtmesi, Edirne Kırmızısı'nın kent kimliğine kazandırılması yönündeki çalışmaların geçerlilik kazandığı gerçeğiyle örtüşmektedir.

6.4. Edirne Kırmızısı’nın Ürün Olarak Çeşitlendirilmesine Ait Bulgular

Katılımcılara "Edirne Kırmızısı bir ürün olsa ne olurdu?" sorusu yöneltilerek Edirne Kırmızısı'nın ürün çeşitlendirilmesinin ölçülmesi hedeflenmiştir. Sorunun devamında ise katılımcılara Edirne Kırmızııı'nı hangi beş üründe görmek istedikleri sorulmuştur. Alınan cevaplar doğrultusunda 10 ayrı tema ortaya çıkmıştır. Katılımcılardan birden fazla cevap istendiği için toplamda 61 cevap alınmıştır. 


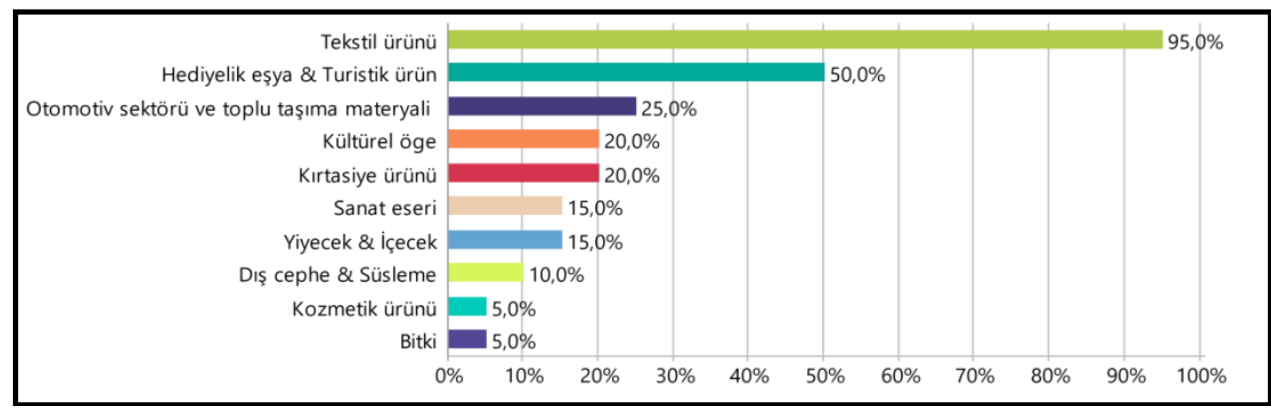
Yüzdesi

Grafik 3: Edirne Kırmızısı'nın Ürün Olarak Çeşitlendirilmesine Verilen Cevapların

Cevaplar analiz edildiğinde katılımcıların \%95'i $(n=19)$, Edirne Kırmızısı'nın bir tekstil ürünü olması gerektiği yönünde görüş bildirmiştir. Bir tek K2 kodlu katılımcı tekstil ürünü dışında yanıt vermiştir. Ayrıca K16 kodlu katılımcı Edirne Kırmızısı'nın her türlü üründe kullanılabileceğini belirtmiş fakat seçeneklerde özellikle tekstil ürünlerini içeren bir ürün ismi vermemiştir. K7 kodlu katılımcı ise Edirne Kırmızııı'nın tekstil ürünü dışında hiçbir yerde kullanılmaması gerektiğini belirterek tek bir ürün ismi vermiştir.

Katılımcıların \%50'si (n=5) Edirne Kırmızısı'nı “hediyelik eşya ve turistik ürün" (olarak çeşitlendirmiştir. Katılımcıların \%25'i $(\mathrm{n}=5)$ Edirne Kırmızısı'nı "otomotiv sektörü ve toplu taşıma materyali”, \%20'si (n=4) “kültürel öge”, \%20'si ise $(n=4)$ "kırtasiye ürünü" olarak yorumlamıştır. Ayrıca katılımcıların \%15'i $(n=3)$ Edirne Kırmızısı'nı "sanat eseri”, \%15'i (n=3) "yiyecek ve içecek”, \%10’u (n=2) "dış cephe ve süsleme", $\% 5$ 'i $(n=1)$ "kozmetik ürünü" ve \%5'i $(n=1)$ "bitki” olarak çeşitlendirmiştir. Kadın katılımcıların tamamı Edirne Kırmızısı'nı bir tekstil ürünü, $\% 80$ 'i ise $(n=20)$ turistik ürün veya hediyelik eşya olarak yorumlamıştır.

Edirne Kırmızısı'nın ilk olarak bir tekstil ürününde ortaya çıkması, katılımcıların bu soruya verdiği yanıtlarda da etkisini göstermektedir. Katılımcıların tamamına yakını Edirne Kırmızısı'nı ağılıklı olarak kravat, şal ve fular gibi bir tekstil ürünü ile çeşitlendirirken hediyelik eşya diyen katılımcıların oranı da yarı yarıya olarak dikkat çekmektedir. Edirne Kırmızısı ile ilgili kentte yürütülen çalışmaların başını çeken Trakya Üniversitesi de bu araştırmadan çıkan sonucu dikkate alarak Kiğılı firması ile yapılan iş birliği kapsamında ipek ve polyester olmak üzere kravat, şal ve mendilden oluşan bir koleksiyon hazırlamıştır. Edirne Kırmızısı'nın otomotiv sektörü ve toplu taşıma materyali olarak da kullanılabileceği yönünde görüş bildiren katılımcıların oranı \% 25 'tir. Rengin taksi ve bisiklet gibi ulaşım araçlarında kullanımı yerel pazarı, otomotiv sektöründen bir marka tarafından kullanımı ise global pazarı kapsamaktadır. Bu doğrultuda Edirne Kırmızısı'nın ticari bir ürün olarak hem yerelde hem de dünya çapında kullanımının yaygınlaşabileceği öngörülmektedir. Araştırmadan elde edilen veriler 
Edirne Kırmızısı'nın gıda sektöründe de kullanılabileceğini ortaya koymuştur. Katılımcılar özellikle dondurma, lokum ve bademezmesi gibi ürünlere Edirne Kırmızısı'nın renk tonunun uygulanabileceğini ve bu sayede rengin kullanım çeşitliliğinin artacağı yönünde görüş bildirmişlerdir.

\section{Bulgular}

6.5. Edirne Kırmızısı ile İlgili Yapılan Çalışmaların Yeterliliğine İlişsin

Edirne Kırmızısı ile ilgili yürütülen çalışmaların yeterli olup olmadığının ölçülebilmesi için katılımcılara "Edirne Kırmızısı'nın kent kimliğine kazandırılması yönündeki çalışmaları nasıl değerlendiriyorsunuz?" sorusu yöneltilmiştir. Cevaplar incelendiğinde "yeterli" cevabını veren katılımcı oranı $\% 40(n=8)$, "süreç yavaş" (cevab1 veren katılımc1 oranı ise $\% 30(n=6)$ olmuştur. Çalışmaları yetersiz bulan, Trakya Üniversitesi'nin bu çalışmalarda önemli bir rol üstlendiğini belirten ve çalışmalar hakkında bilgi sahibi olmadığını ifade eden katılımc1 oranları ise $\% 10(\mathrm{n}=2)$ olmuştur.

Edirne Kırmızısı ile ilgili yapılan çalışma ve faaliyetlere ilişkin ortaya çıkan en yüksek orana sahip "yeterli" teması ile "Trakya Üniversitesi'nin rolü” teması $\% 50(n=10)$ oranını bulmaktadır. Bu oran, Edirne Kırmızısı ile ilgili bugüne kadar yapılan çalışma ve faaliyetlerin verimliliğini ortaya koyduğu gibi akademik ve bilimsel çalışmalara ağırlık veren Trakya Üniversitesi'nin de önemli bir görev üstlendiği görüşünü doğrulamaktadır.

\section{Dair Bulgular}

6.6. Edirne Kırmızısı'nın Yaygınlaștırılması ile İlgili Yapılan Önerilere

Edirne Kırmızısı isminin yaygınlaşması ve rengin kent kimliğine kazandırılması yönünde yapılabilecek faaliyet ve çalışmaların çeşitliliğin artırılması adına katılımcılardan birtakım öneriler toplanmıştır. Her katılımcı birden fazla cevap verdiği için 11 tema oluşmuştur.

Ortaya çıkan temalara bakıldığında katılımcıların \%29,4'ü “Edirne Kırmızısı Müzesi kurulması", \%23,5'i de "Edirne Kırmızısı Festivali düzenlenmesi” yönünde görüş bildirmiştir. "Tanıtım ve bilgilendirme yapılması", "akademik çalışmaların yapılması", "Edirne Kırmızısı'nın kent kültürü ve kimliğine kazandırılması" ve "Edirne Kırmızısı'nın renk analizinin yapılması" temalarının oranı \%23,5'tir. “Edirne Kırmızısı'nı içeren ürün çeşitliliğinin artması" ve "Edirne Kırmızısı heykelinin yapılması" temaları oranı \%17,6; "Edirne Kırmızısı'nın gida ve hizmet sektöründe kullanılması" ve "Edirne Kırmızısı atölyesi kurulması" temaları oranı da \%11,8'dir. "Taklit ve etik olmayan pazarlamanın önüne geçilmesi" temasının oran 1 ise $\% 5,9$ 'dur.

Edirne Kırmızısı'nın kent kimliğine kazandırılması çalışmalarında ortaya sunulan önerilerden en yüksek orana sahip olan "Edirne Kırmızısı Müzesi kurulması" teması, Grafik 7'de bahsedildiği gibi Edirne Kırmızısı'nın kültürel bir ögeyi ifade ettiği görüşünü desteklemektedir. "Edirne Kırmızısı Festivali 
düzenlenmesi”, "Edirne Kırmızısı'nın kent kültürü ve kimliğine kazandırılması", "Edirne Kırmızısı heykelinin yapılması" ve "Edirne Kırmızısı atölyesi kurulması" temaları da bu görüşü ayrıca desteklediği gibi rengin sürdürülebilirlik potansiyelini de ortaya koymaktadir.

\subsection{Edirne Kırmızısı ile İlgili Gelecekteki Olumlu Tahminlere İlişskin}

\section{Bulgular}

Edirne Kırmızısı'nın gelecekte olumlu yönden neler beklediğinin ölçülmesi için katılımcılara "Edirne Kırmızısı kavramının gelecekte yerel ya da ulusal çapta kullanımı ile ilgili olumlu tahminleriniz nelerdir?" sorusu sorulmuş ve cevaplar doğrultusunda ortaya üç tema çıkmıştır. Ortaya çıkan temalara bakıldığında Edirne Kırmızısı'nın gelecekte bir marka haline geleceği temasını ifade eden katılımcı oranı \%55 ( $\mathrm{n}=11)$, Edirne Kırmızısı'nın ekonomiye katk1 sunacağı temasını belirten katılımc oranı \%25 (n=5) ve Edirne Kırmızısı'nın ilgi ve merak uyandıracağı temasını ifade eden katılımcı oranı $\% 20(n=4)$ olmuştur.

\section{Bulgular}

6.8. Edirne Kırmızısı ile İlgili Gelecekteki Olumsuz Tahminlere İlişkin

Edirne Kırmızısı'nın gelecekte olumsuz yönden neler beklediğinin ölçülmesi için katılımcılara "Edirne Kırmızısı kavramının gelecekte yerel ya da ulusal çapta kullanımı ile ilgili olumsuz tahminleriniz nelerdir?" sorusu sorulmuştur.

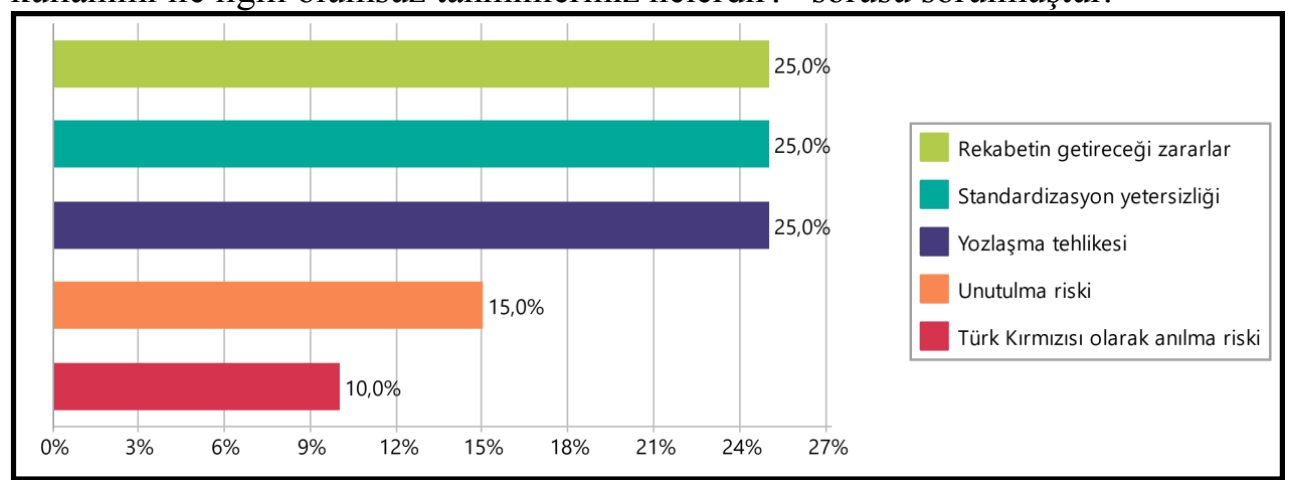

Grafik 4: Edirne Kırmızısı ile İlgili Gelecekteki Olumsuz Tahminlere İliş̧in Verilen Cevapların Yüzdesi

Temalar incelendiğinde "rekabetin getireceği zararlar" cevabı veren katılımcı oranı \%25 $(\mathrm{n}=5)$, "standardizasyon yetersizliği" cevabını veren katılımcı oranı $\% 25(n=5)$ ve "yozlaşma tehlikesi" cevabını veren katılımcı oranı $\% 25(n=5)$ olmuştur. Edirne Kırmızısı'nın "unutulma riski” taşıdığını belirten katılımeı oranı \%15 ( $\mathrm{n}=3)$ ve Edirne Kırmızısı'nın "Türk Kırmızısı olarak anılma riski” ile karşılaşılacağını ifade eden katılımcı oranı ise \%10 (n=2) olmuştur.

Edirne Kırmızısı ile ilgili gelecekteki olumsuz tahminlerin analizine bakıldığında birbiriyle ilintili olduğu saptanan "rekabetin getireceği zararlar", 
"standardizasyon yetersizliğiı", "yozlaşma tehlikesi” ve "Edirne Kırmızısı'nın Türk Kırmızısı olarak anılma riski" temaları toplamda \%85 (n=17) oranına ulaşmaktadır. $\mathrm{Bu}$ oran, Edirne Kırmızısı ile ilgili yapılan çalışmaların sürdürülebilir olmayacağı endişesini yansıtmaktadır.

\section{SONUÇ VE ÖNERILER}

Kent genelinde sınırlı sayıda tarihçi, araştırmacı ve konuya özel ilgi duyan akademisyenler tarafından bilindiği gözlenen Edirne Kırmızısı'nın bilinirliği 2017 yılında Edirne Hudut Gazetesi'nde yayımlanan bir yazı dizisi sonrası artmıştır. 1999 yılında halk arasında konuşulan, 2005 yılında Edirne Valiliği tarafından çıkarılan bir dergide makaleye konu olan Edirne Kırmızısı'nın kent kimliğine kazandırılması yönünde birçok resmi kurum ve sivil toplum kuruluşu, 2017 yılından itibaren çalışmalar yürütmektedir. $\mathrm{Bu}$ kurum ve kuruluşların başında Trakya Üniversitesi ile Edirne Tanıtım ve Turizm Derneği gelmektedir. Bu çalışmalara yerel halk ve esnaf da dâhil olmuştur. 2017 yılından sonra Edirne Kırmızısı'nın mesleki proje ve toplantılara, bilimsel çalışmalara ve çeşitli iletişim araçlarına konu olması Edirne Kırmızısı'nın bilinirliğine katkıda bulunmuştur.

Edirne Kırmızısı sadece bir rengi değil, kültürel bir öge olarak somut ve soyut kavramları da temsil etmektedir. Bu araştırmada Edirne Kırmızısı'nı kültürel bir öge olarak betimlenmesi, rengin kent kimliğine kazandırılması çalışmalarının geçerliliğini ortaya koymaktadır. Trakya Üniversitesi'nin hayata geçirdiği çalışma ve faaliyetlerin Edirne Kırmızısı'nın tanıtımında çok büyük bir etkisi olmuştur. Bu durum, Trakya Üniversitesi'nin etkinliğini ve Edirne Kırmızısı konusunda lokomotif kurum olabileceğini göstermektedir.

Edirne Kırmızısı'nın ilk olarak bir tekstil ürününde ortaya çıkması, araştırmada sorular yöneltilen katılımcılar üzerinde de etkisini göstermektedir. Katılımcıların tamamına yakını Edirne Kırmızısı'nı kravat, şal ve fular gibi tekstil ürünleri ile çeşitlendirmiştir. Edirne Kırmızısı ile ilgili çalışmalarda öncü kurumlardan biri olan Trakya Üniversitesi de bu araştırma kapsamında bir giyim firması ile iş birliğine giderek kravat, şal ve mendilden oluşan bir koleksiyon hazırlamıştır. Trakya Üniversitesi'nin Edirne Kırmızısı üzerindeki yetkinliğini gösteren koleksiyon aynı zamanda bu araştırmanın da bir çıktısı olarak dikkat çekmektedir. Edirne Kırmızısı'nın ürün ve objelerde kullanımı ileriki süreçte kent ekonomisine katkı sağlayacağını göstermektedir. Bu araştırmanın en önemli sonuçlarından biri Edirne Kırmızısı'nın ticari bir ürün olarak hem yerelde hem de dünya çapında kullanımının yaygınlaşacağı, gelecekte büyük bir marka haline geleceği öngörüsüdür. Bu öngörü, Edirne ilinin "marka kent” kavramı ile de örtüşmektedir. 2019 y1lında yaşanan, bütün dünya ekonomisini ve özellikle turizm sektörünü etkileyen Covid-19 küresel salgını turist beklentilerini ve algılarını değiştirmiş̧tir. Kitle turizmi yerini alternatif turizm olanakları çerçevesinde kültür turizmi ve kent turizmi daha da önem kazanacağı görüşü ön plana çıkmıştır. Edirne 
Aralık 2021 Cilt 23 Sayı 2 (941-962)

Kırmızısı da temsil ettiği tarihi, kültürel ve turistik özellikleriyle Edirne kentini dünyaca tercih edilen seçkin destinasyonlar arasına girmesine katkıda bulunacaktır.

Bilimsel araştırmaların yanı sıra Edirne Kırmızısı'nı yerel ekonomiyle bütünleştirecek çalışmaların yapılması, Edirne Kırmızısı'nın tüm üretim aşamalarının yer aldığı, kentsel turizmi de destekleyerek turistlerin farklı bir deneyim yaşayabileceği bir çalışma atölyesi kurulması gerekliliği ortaya çıkmıştır. Özellikle boya ve tekstil firmalarının Edirne Kırmızısı rengini elde edebilmek için profesyonel çalışmalar yapması ve bu renkte üretilecek ürünleri belirli bir standardizasyona ulaştırması, Edirne Kırmızısı'nın yozlaşma tehlikesini ortadan kaldıracaktır. Trakya Üniversitesi ev sahipliğinde gerçekleştirilen kongre ve sempozyumlarda Edirne Kırmızısı'nın kullanılması, rengin ulusal ve uluslararas tanınırlığını farklı boyutlara ulaştıracaktır. Sosyal medya tanıtımının üzerine gidilmesi de Edirne Kırmızısı'nın daha geniş kitlelere ulaşmasını sağlayacaktır.

\section{KAYNAKÇA}

Cardon D. (1995). “Aussi Rouge Que Possible: L'art Du Teinturier Face A L'eternel Desir Du Rouge”. Adnrinople: Le Rouge Magnifique, s.72-79, Paris.

Çoruhlu, Y. (2000). "Türk Mitolojisinin Anahtarları". Kabalcı Yayınevi, s.191-192.

Demir, R. (2015). "Divan Şiirinde Kırmızı Renk”. Türkiyat Mecmuası, 25(1), 57-91.

Dokumac1, M. (2020). "Renklerin İnsan Yaşamındaki Etkileri ve Renklerin Tarih Boyunca Yolculuğu”. Takvim-i Vekayi, 8(2), 120-131.

Eren, A. (2008). "Bâkî Divanı'nda Kırmızı Renk". Atatürk Üniversitesi, Sosyal Bilimler Enstitüsü Dergisi, 37, 31-68.

European Commission. (2000). "Towards Quality Urban Tourism, Integrated Quality Management (IQM) of Urban Tourist Destinations". Brussels: European Communities Publications.

İçli, G. E. ve Çopur, M. E. (2008). "Pazarlama İletişiminde Renklerin Rolü”. Trakya Üniversitesi Sosyal Bilimler Dergisi, 10(1), 22-33.

İçellioğlu, C. Ş. (2014). "Kent Turizmi ve Marka Kentler: Turizm Potansiyeli Açısından İ́stanbul'un Swot Analizi”. Sosyal Bilimler Dergisi, (1), 37 55 . 81. Paris.

Jacque, J. (1995). "Introduction”. Adnrinople: Le Rouge Magnifique, s. 80-

Kavruk, H. (2002). “Anakente Bakış”. Hizmet İş Sendikası Yayınları, s.65. Ankara.

Koyuncu, A. (2011). "Sosyoloji Kuramlarında Kent”. Selçuk Üniversitesi Edebiyat Fakültesi Dergisi, (25), 31-56.

Landry, C. ve Murray, C. (2017). "Psychology \& The City: The Hidden Dimension". Gloucestershire: Comedia. 
Yıldırım, L. (2014). “Avrupa Tekstil Baskıcılığının Gelişiminde Türk Kırmızısı'nın Rolü”, Yedi. (12), 11-22.

Meydan Larousse. (1992). Sabah Gazetesi Yayınları, Cilt 16, İstanbul.

Meyers, H. M. ve Lubliner, M. J. (2003). "Başarılı Ambalaj Başarılı Pazarlama”. (Çeviren: Z. Üsdiken), Rota Yayınları, İstanbul.

Ögel, B. (1984). "Türklerde Tuğ ve Bayrak”. Türk Kültür Tarihine Giriş, c. VI, s. 401. Ankara.

Özer, Uca, S. (2010). "Şehir Turizmi ve Kültür: Yabanc1 Turistlerin Kültürel Bir Destinasyon Olarak İstanbul'u Değerlendirmeleri Üzerine Bir Araştırma". (Yayımlanmamış Doktora Tezi). Anadolu Üniversitesi Sosyal Bilimler Enstitüsü Turizm ve Otel İşletmeciliği Anabilim Dalı. Eskişehir.

Topal, A. K. (2004). 'Kavramsal Olarak Kent Nedir ve Türkiye'de Kent Neresidir?”. Dokuz Eylül Üniversitesi Sosyal Bilimler Dergisi, c. 6, s. 1, İzmir. Madrid.

World Tourism Organization. (2012). "Global Report on City Tourism". 6,

Yürek, D. (2021). "Edirne: Muhteşem Kırmızı". Edirne Tanıtım ve Turizm Derneği Dergisi. s.2, 56-59.

\section{İnternet Kaynakları}

Besalel, Y. "Mevcudu Kalmamış Bir Yahudi Cemaati: Edirne". https://www.salom.com.tr/arsiv/haber-93789-

mevcudu_kalmamis_bir_yahudi_cemaati_edirne.html._(Erişim Tarihi: 30.05.2021)

Çağlar, S. (2019). "Antik Çağdan Günümüze Kırmızı Rengin Tarihçesi”. https://www.matematiksel.org/antik-cagdan-gunumuze-kirmizi-rengin-tarihcesi/ (Erişim Tarihi: 21.04.2021)

Karadağ, R. (2007). "200 Yıldır Kayıp Türk Kırmızısı Yeniden Doğdu”. http://www.gazetevatan.com/200-yildir-kayip-turk-kirmizisi-yeniden-dogdu1083059-pazar-vatan/ (Erişim Tarihi: 16.05.2021)

Ure, A. (1844). "A Dictionary of Arts, Manufactures, and Mines." 3rd ed., New York: $\quad$ D. $\quad$ Appleton \& Company, http://books.google.co.uk/books?id=6zEKAAAAIAAJ\&printsec=frontcover\&sour $\mathrm{ce}=\mathrm{gbs}$ ge_summary_r$\& \mathrm{cad}=0 \# \mathrm{v}=$ onepage $\& \mathrm{q} \& \mathrm{f}=\mathrm{false} . \quad$ (Erişim Tarihi: 17.03.2021)

Wertz, J. (2014). “Turkey Red”. https://indiastreetbazaar.net/stories/turkeyred/ (Erişim Tarihi: 13.02.2021) 